\title{
OPTIMALISASI PELAKSANAAN METODE CONTOH KASUS DAN DISKUSI INTERAKTIF UNTUK MENINGKATKAN PRESTASI BELAJAR AGAMA HINDU
}

\author{
Oleh: \\ Anak Agung Sagung Diah Yuliardayani \\ diahyuliardayani@yahoo.co.id \\ Guru Agama Hindu di SMP Negeri 6 Denpasar
}

Proses Review 10-24 September, Dinyatakan Lolos 28 September

\begin{abstract}
This research was conducted at SMP Negeri 6 Denpasar in Class VIII where the ability of students in Hindu subjects was still low. The purpose of this study is to find out whether the case example method and interactive discussion in expository learning can improve student achievement in Hindu Religion. The data collection method is a learning achievement test. The data analysis method is descriptive. The results obtained from this study are the case sample method and interactive discussion in Expository learning can improve student learning achievement, where initially the average value of students was 69.87 after given action in the first cycle increased to 76.45 and in the second cycle increased again to 81.71. The conclusion obtained from this study is the method of case examples and interactive discussion in expository learning can improve student achievement in class VIII SMP Negeri 6 Denpasar.
\end{abstract}

Keywords: Case Examples, Interactive Discussion, Expository, Learning Achievement

\begin{abstract}
Abstrak
Penelitian ini dilakukan di SMP Negeri 6 Denpasar di Kelas VIII yang kemampuan siswanya dalam mata pelajaran Agama Hindu masih rendah. Tujuan dari penelitian ini adalah untuk mengetahui apakah metode contoh kasus dan diskusi interaktif dalam pembelajaran Ekspository dapat meningkatkan prestasi belajar Agama Hindu siswa. Metode pengumpulan datanya adalah tes prestasi belajar. Metode analisis datanya adalah deskriptif. Hasil yang diperoleh dari penelitian ini adalah metode contoh kasus dan diskusi interaktif dalam pembelajaran Ekspository dapat meningkatkan prestasi belajar siswa, dimana pada awalnya nilai rata-rata siswa adalah 69,87 setelah diberikan tindakan pada siklus I meningkat menjadi 76,45 dan pada siklus II meningkat lagi menjadi 81,71. Kesimpulan yang diperoleh dari penelitian ini adalah metode contoh kasus dan diskusi interaktif dalam pembelajaran Ekspository dapat meningkatkan prestasi belajar siswa kelas VIII SMP Negeri 6 Denpasar.
\end{abstract}

Kata Kunci : Contoh Kasus, Diskusi Interaktif, Ekspository, Prestasi Belajar 


\section{PENDAHULUAN}

Sekolah sebagai tempat proses belajar mempunyai kedudukan yang sangat penting dan menonjol dalam dunia pendidikan. Oleh karena itu, pendidikan di sekolah memegang peranan penting dalam rangka mewujudkan tercapainya pendidikan Nasional secara optimal seperti yang diharapkan. Proses belajar mengajar merupakan inti dari proses pendidikan. Dalam proses belajar mengajar tersebut, guru menjadi pemeran utama dalam menciptakan situasi interaktif yang edukatif, yakni interaksi antara guru dan siswa, siswa dengan siswa dan dengan sumber pembelajaran dalam menunjang tercapainya tujuan belajar.

Hasil yang diperoleh menyangkut penguasaan materi pelajaran Agama Hindu pada awal semester pada siswa kelas VIII ${ }^{6}$ SMP Negeri 6 Denpasar Kota Denpasar ternyata masih belum mencapai standar minimal seperti yang ditetapkan. Rata-rata nilai dalam mata pelajaran Agama Hindu yang diperoleh masih di bawah KKM yaitu 69,87. Daya serap siswa terhadap materi pelajaran hanya $32,26 \%$ atau dapat dikatakan bahwa siswa yang tergolong berhasil mencapai ketuntasan belajar sesuai yang diharapkan adalah 10 orang dari total 31 siswa. Sisa siswa yang lainnya sebanyak 11 orang tergolong tidak tuntas karena prestasi belajarnya masih berada di bawah KKM yaitu 78,00. Adapun langkah yang diambil untuk memperbaiki prestasi belajar siswa yaitu dengan melakukan tindakan perbaikan yang selanjutnya disusun dalam bentuk penelitian tindakan kelas. Pada langkah awal, guru mencari masalah-masalah yang mengganggu dan menghambat penguasaan siswa terhadap mata pelajaran ini yaitu rendahnya motivasi belajar siswa, kurang tertariknya mereka terhadap mata pelajaran Agama Hindu. Setelah permasalahan didapat, maka dilakukan tindakakn kelas dengan penggunaan model pembelajaran ekspository untuk meningkatnya prestasi belajar mereka.

Upaya untuk memperbaiki praktek dalam pembelajaran agar lebih berkualitas dalam prosesnya, agar lebih meningkat hasil belajar yang diperoleh siswa menjadi tujuan dari penelitian ini dan dirumuskan sebagai berikut: untuk mengetahui seberapa tinggi peningkatan prestasi belajar anak setelah diterapkan metode bercerita yang dibantu dengan pemberian tugas dalam pembelajaran Agama Hindu. Secara teoritis, hasil penelitian ini diharapkan akan bermanfaat sebagai acuan dalam memperkaya teori dalam rangka peningkatan kompetensi guru. Sedangkan secara praktis penelitian ini diharapkan bermanfaat: 1) Bagi guru-guru yang mengajar mata pelajaran Agama Hindu, hasil penelitian ini diharapkan dapat dijadikan acuan dalam menyusun strategi pembelajaran untuk dapat meningkatkan prestasi belajar siswa. Disamping hasil itu hasil penelitian ini dapat digunakan sebagai bahan pertimbangan dalam memilih model yang mampu meningkatkan prestasi belajar siswa sehingga dominasi guru dalam pembelajaran dapat ditekan. Model ini mampu menumbuhkan cara pikir bahwa guru tidak lagi harus mendominasi waktu siswa dalam belajar, dapat menumbuhkan ide dan kreativitas dalam merencakana pembelajaran yang mampu membuat para siswa lebih bersemangat, lebih senang dan lebih kreatif. 2) Bagi sekolah, hasil penelitian dapat meningkatkan kualitas pendidikan di sekolah, dapat digunakan sebagai bahan kajian dalam upaya peningkatan mutu, dapat dijadikan bahan kajian dalam pembelajaran yang berhubungan dengan mata pelajara Agama Hindu. 3) Begi peserta didik, dapat memberikan pengalaman mengenal model pembelajaran yang baru ynag sangat bermanfaat untuk mengembangkan kemampuan intelektual siswa dakan meningkatkan keterampilan berpikir dan bekal bagi merekan untuk dapat memecahkan masalah-masalah dalam kehidupan mereka kelak di masyarakat. 4) Bagi pengawas sekolah, hasil penelitian ini akan sangant bermanfaat sebagai pegangan dalam membina guru-guru di sekolah binaannya.

Dalam Kamus Besar Bahasa Indonesia, kata 'contoh' yang berhubungan dengan penelitian ini berarti teladan (kelakuan, perbuatan, dan sebagainya); hal (seperti peristiwa) yang menjadi teladan. Sedangkan 'kasus' dapat berarti soal atau perkara dapat juga berarti keadaan atau kondisi khusus yang berhubungan dengan seseorang atau suatu hal. Jika istilah kasus itu dihubungkan dengan seseorang, maka 
ini dapat berarti bahwa pada orang yang dimaksudkan terdapat "soal" atau "perkara" tertentu. Dengan demikian, contoh kasus dapat dimaknai sebagai kelakuan, perbuatan, hal atau peristiwa yang berhubungan dengan seseorang yang dapat berarti bahwa pada orang yang dimaksudkan terdapat "soal" atau "perkara" tertentu. Dengan metode contoh kasus, guru menyiapkan beberapa kasus sosial yang ada di masyarakat atau yang merupakan pengalaman pribadi guru dan siswa untuk dijadikan bahan pembelajaran. Kasus sosial yang dijadikan bahan adalah kasus dan peristiwa atau berita yang menyangkut masalah pelanggaran nilainilai dan norma yang terjadi di masyarakat. Kasus atau contoh kasus akan menjadi tugas dari siswa untuk mencari dan memilih sendiri permasalahan yang akan dijadikan kajian. Selanjutnya akan dilakukan dalam diskusi interaktif antara siswa dan guru di dalam kelas.

Terlepas dari pendekatan pembelajaran yang digunakan, pada saat-saat tertentu selama berlangsungnya pembelajaran, diperlukan dialog antara guru dan siswa, serta antara siswa dengan siswa. Diskusi adalah suatu pendekatan pembelajaran yang memungkinkan berlangsungnya dialog tersebut. Sintaks diskusi berbeda dengan sintaks model pembelajaran yang lain. Misalnya, diskusi dapat terjadi pada pembelajaran kooperatif,antara guru dan sejumlah siswa pada pembelajaran berdasarkan masalah, dan resitasi pada pembelajaran langsung. Diskusi merupakan komunikasi dimana khalayak berbicara dengan orang lain, saling membagigagasan dan pendapat. Menurut Martinis Yamin (2009) metode diskusi merupakan metode pembelajaran yang menghadapkan guru pada suatu permasalahan, menjawab pertanyaan, menambah dan memahami pengetahuan siswa, serta untuk membuat suatu keputusan. Selama ini banyak guru yang merasa keberatan untuk menggunakan metode diskusi dalam proses pembelajaran. Keberatan itu biasanya timbul dari asumsi: pertama, diskusi merupakan metode yang sulit diprediksi hasilnya oleh karena interaksi antarsiswa muncul secara spontan, sehingga hasil dan arah diskusi sulit ditentukan; kedua, diskusi biasanya memerlukan waktu yang cukup panjang, padahal waktu pembelajaran di kelas sangat terbatas, sehingga eterbatasan itu tidak mungkin dapat menghasilkan sesuatu secara tuntas.

Roy Killen dalam Wina Sanjaya (2009) menamakan metode ekspositori dengan istilah strategi pembelajaran langsung (Direct Instruction). Karena dalam hal ini siswa tidak dituntut untuk menemukan materi itu. Materi pelajaran seakan-akan sudah jadi. Oleh karena metode ekspositori lebih menekankan kepada proses bertutur, maka sering juga dinamakan istilah metode chalk and talk. Metode ekspositori adalah bentuk pendekatan pembelajaran yang berpusat guru (teacher centered approach). Guru sangat berperan dominan dan fokus utama metode ini adalah kemampuan akademik siswa (academic achievement student). Dibanding metode ceramah, dalam metode ini dominasi guru sudah banyak berkurang. Tetapi jika dibanding dengan metode demonstrasi, metode ini masih nampak lebih banyak didominasi oleh guru. Hal ini sesuai dengan pernyataan Somantri (2001:45) yang menyebutkan perbedaan metode ekspositori dengan metode ceramah bahwa pada metode ekspositori dominasi guru banyak dikurangi. Guru tidak terus bicara, informasi hanya diberikan pada saat atau bagian-bagian yang diperlukan saja, seperti di awal pembelajaran, menjelaskan konsep-konsep dan prinsip baru, pada saat memberikan contoh kasus di lapangan dan sebagainya. Metode ekspositori adalah suatu cara menyampaikan gagasan atau ide dalam memberikan informasi dengan lisan atau tulisan. David P. Ausubel dalam Pentatito Gunowibowo (1998:6.7, dalam http://sucyramdhani.blogspot.com/2010/01/ bab-i-pendahuluan-dalam-kenyataan.html) menyebutkan bahwa metode ekspositori merupakan cara mengajar yang paling efektif dan efisien dalam menanamkan belajar bermakna.

Dalam pembelajaran ekspositori guru cenderung memegang kontrol proses pembelajaran yang aktif, sementara siswa relatif pasif menerima dan mengikuti apa yang disajikan oleh guru. Pembelajaran ekspositori merupakan pembelajaran yang lebih berpusat pada guru (teacher centered), guru menjadi sumber dan pemberi informasi utama. Model pembelajaran yang berpusat pada guru ini 
memiliki keunggulan: 1) bahan belajar dapat disampaikan secara tuntas, 2) dapat diikuti oleh siswa dalam jumlah besar, 3) pembelajaran dapat dilaksanakan sesuai dengan alokasi waktu yang ditetapkan, 4) target materi relatif mudah dicapai. Sedangkan kelemahannya yang dapat terjadi adalah: 1) membosankan, 2) keberhasilan perubahan sikap dan prilaku peserta didik relatif sulit diukur, 3) kualitas pencapaian tujuan belajar yang telah ditetapkan adalah relatif rendah karena pendidik sering hanya mengejar target waktu untuk menghabiskan target materi pembelajaran, dan pembelajaran kebanyakan menggunakan ceramah dan jawab (Sudjana, 2005: 39).

Prestasi belajar pada hekekatnya adalah hasil dicapai setelah terjadinya komunikasi edukatif dari hubungan timbal balik antara dua hal atau lebih atau pribadi-pribadi yang sama, dengan tujuan mengarahkan pada satu tujuan tertentu yang akan dicapai. Djamarah (1994:23) mendefinisikan prestasi belajar sebagai hasil yang diperoleh berupa kesan-kesan yang mengakibatkan perubahan dalam diri individu sebagai hasil dari aktivitas dalam belajar. Kalau perubahan tingkah laku adalah tujuan yang mau dicapai dari aktivitas belajar, maka perubahan tingkah laku itulah salah satu indikator yang dijadikan pedoman untuk mengetahui kemajuan individu dalam segala hal yang diperolehnya di sekolah. Dengan kata lain prestasi belajar merupakan kemampuan-kemampuan yang dimiliki oleh siswa sebagai akibat perbuatan belajar atau setelah menerima pengalaman belajar, yang dapat dikatagorikan menjadi tiga ranah, yakni ranah kognitif, afektif, dan psikomotor. Sardiman (1988: 25) menyatakan prestasi belajar sangat vital dalam dunia pendidikan, mengingat prestasi belajar itu dapat berperan sebagai hasil penilaian dan sebagai alat motivasi. Abdullah (dalam Mamik Suratmi, 1994: 22), mengatakan bahwa fungsi prestasi belajar adalah: (a) sebagai indikator dan kuantitas pengetahuan yang telah dimiliki oleh pelajar, (b) sebagai lambang pemenuhan keingintahuan, (c) informasi tentang prestasi belajar dapat menjadi perangsang untuk peningkatan ilmu pengetahuan dan (d) sebagai indikator daya serap dan kecerdasan murid.

Rumusan hopotesis pada umumnya menggambarkan tentang alternatif tindakan yang diyakini dapat menyelesaikan masalah yang dihadapi untuk itu perumusan hipotesis dalam penelitian ini adalah: Apabila metode contoh kasus dan diskusi interaktif dilaksanakan secara baik dalam model pembelajaran Ekspository akan mampu meningkatkan prestasi belajar Agama Hindu pada siswa Kelas VIII ${ }^{6}$ SMP Negeri 6 Denpasar Semester II Tahun Pelajaran 2016/2017.

\section{METODE}

Lokasi di SMP Negeri 6 Denpasar sangat tepat untuk melakukan penelitian tindakan kelas karena rendahnya prestasi belajar siswa. Sekolah ini beralamat di Jalan Gurita, Sesetan Denpasar Selatan. Penelitian tindakan didasarkan pada filosofi bahwa setiap manusia tidak suka atas hal-hal yang statis, tetapi selalu menginginkan sesuatu yang lebih baik. Peningkatan diri untuk hal yang lebih baik ini dilakukan terus menerus sampai tujuan tercapai (Suharsimi Arikunto, Suhardjono, Supardi, 2006: 67). Berikut disampaikan pedoman pelaksanaan penelitian yang telah beliau rancang.

Rancangan sangat perlu dibuat dalam sebuah penelitian. Rancangan yang hanya merupakan tulisan rangkaian mesti dijelaskan secara mendalam dalam prosedur yang akan dilakukan dengan keterangan-keterangan yang lengkap. Karena dengan penjelasan yang lengkap akan dapat diketahui alur penelitian yang dilaksanakan. Untuk itu peneliti menjelaskan prosedur yang dilakukan adalah mulai dengan adanya suatu permasalahan. Setelah diketahui ada masalah, dibuat perencanaan, kemudian dilaksanakan, diamati dan dilakukan refleksi. Setelah refleksi akan terlihat permasalahan yang tersisa yang merupakan masalah baru. Dengan adanya masalah baru maka dibuat perencanaan ulang, dilaksanakan, diamati dan dilakukan refleksi. Bila permasalahan belum bisa diatasi maka dilanjutkan dengan siklus berikutnya.

Subjek penelitian ini adalah semua siswa kelas VIII $^{6}$ semester II Tahun Pelajaran 2016/2017 merupakan subyek dalam penelitian ini. Rendahnya prestasi belajar siswa merupakan 


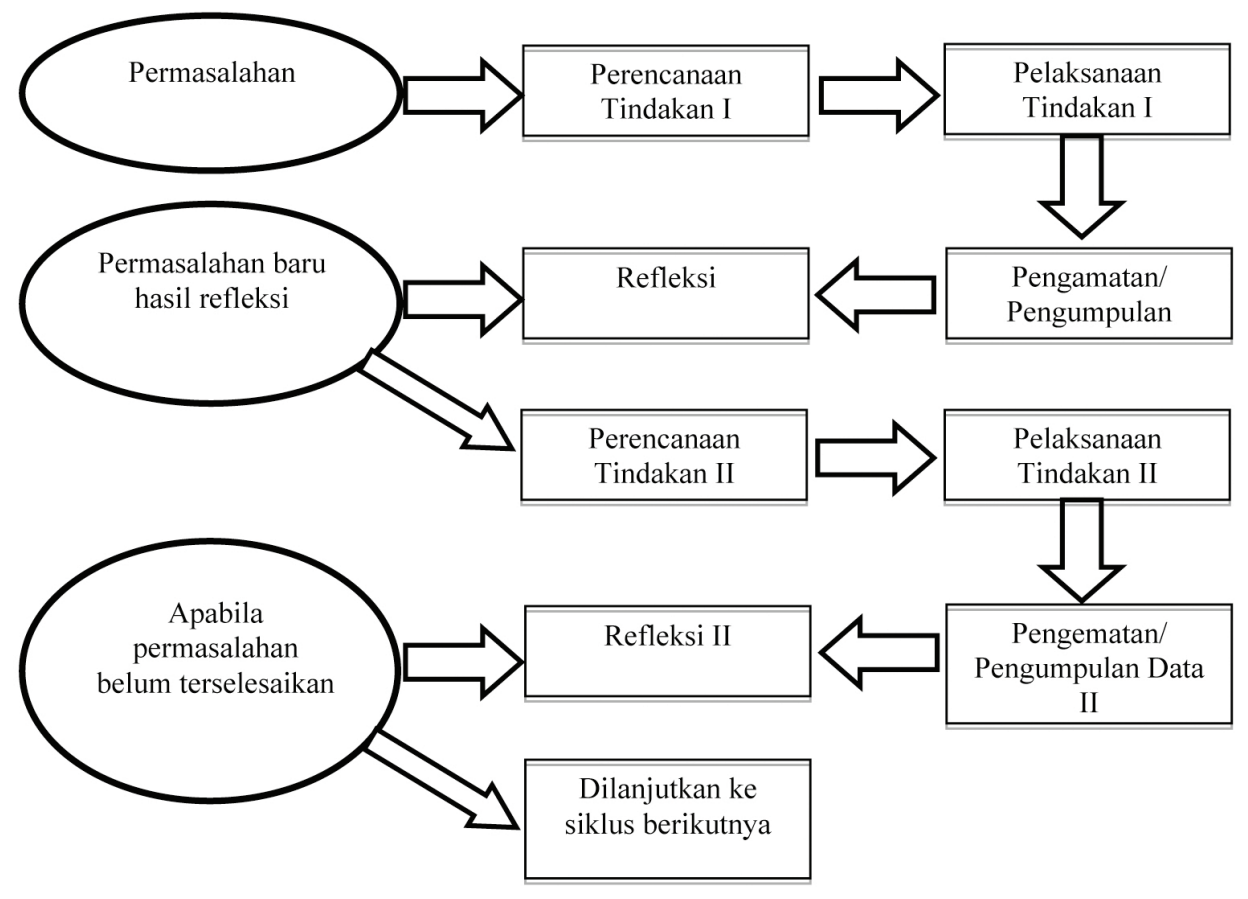

Gambar 1.

Alur Penelitian Tindakan Kelas

(dalam Suharsimi Arikunto, Suhardjono, Supardi, 2007:74)

focus penelitian peneliti dalam penelitian ini. Hal tersebut dijadikan obyek penelitian agar mampu diupayakan peningkatannya. Dengan diterapkan model ekspository dalam proses pembelajaran menggunakan metode contoh kasus dan diskusi interaktif. Pelaksanaan penelitian tindakan kelas ini dimulai dari bulan Januari sampai bulan Mei 2017. Penelitian Tindakan Kelas ini menggunakan cara pengumpulan data yaitu pemberian tes prestasi belajar. Hasil yang diperoleh dari penelitian ini adalah data dalam bentuk angka, oleh karenanya analisis yang dilakukan adalah dengan mencari mean, median, modus, membuat interval kelas dan melakukan penyajian dalam bentuk tabel dan grafik. Alat untuk menilai kemampuan siswa adalah tes prestasi belajar. Ala/instrument tersebut ada di masing-masing RPP di lampiran. Penelitian ini terdiri dari dua siklus. Indikator keberhasilan pada siklus I yang diusulkan rataratanya sebesar 78 dengan ketuntasan belajar minimal $80 \%$. Pada siklus II indikator keberhasilan yang diusulkan rata-ratanya sebesar 78 atau lebih dengan ketuntasan belajar minimal $85 \%$ atau lebih.

\section{HASIL PENELITIAN DAN PEMBAHASAN}

Gambaran hasil penelitian ini dimulai dari mendeskripsikan data awal yang di dapat, berlanjut dengan pemaparan tindakan siklus I dan siklus II dimulai dengan perencanaan, pelaksanaan, hasil observasi dan refleksi yang dilakukan terkait tahapan yang sudah dilakukan.

Deskripsi Awal. Gambaran yang diperoleh dari data awal adalah banyaknya peserta didik yang nilai prestasi belajar awalnya rendah yaitu 21 orang $(67,74 \%)$. Hanya ada 10 siswa $(32,26 \%)$ yang mampu memperoleh keberhasilan sesuatu harapan. Hal ini merupakan ciri bahwa sebagian besar anak membutuhkan bimbingan dan pengarahan serius untuk dapat meningkatkan prestasi belajar mereka khususnya mata pelajaran Agama Hindu.

\section{Deskripsi Siklus I}

Perencanaan I. Perencanaan Siklus I ini disusun sedemikian rupa untuk merancang cara membantu peserta didik mampu meningkatkan prestasi belajarnya. Adapun persiapan yang 
direncanakan yaitu : 1) Menyusun jadwal kegiatan pelaksanaan penelitian. 2) Menyusun rencana pelaksanaan pembelajaran (RPP). 3) Membicarakan hal-hal penting bersama temanteman guru membicarakan alat-alat peraga, bahan-bahan yang bisa membantu peningkatan prestasi belajar peserta didik, merencanakan model pembelajaran yang paling tepat untuk digunakan dalam pembelajaran. 4) Menyusun format penilaian. 5) Menyiapkan bahan-bahan pendukung pembelajaran lainnya. 6) Merancang skenario pembelajaran.

Pelaksanaan I. 1) Mulai memasuki kelas dengan membawa persiapan-persiapan ajar. 2) Memasuki kelas guru memberi salam pada peserta didik. 3) Guru menyampaikan materi pelajaran dan mengajak peserta didik belajar lebih giat. 4) Melaksanakan pembelajaran sesuai pada perencaan yang telah disusun.

Observasi I. Observasi dilakukan dengan cara: 1) Menilai unjuk kerja peserta didik setelah melaksanakan tugas yang disuruh. 2) Mengobservasi kegiatan yang dilakukan peserta didik.

Refleksi I. Kajian secara menyeluruh tindakan yang telah dilakukan merupakan refleksi yang akan disampaikan pada bagian ini. Refleksi dilakukan berdasar data yang telah terkumpul, kemudian dilakukan evaluasi guna penyempurnaan tindakan. Semua ini dilakukan untukdapatmenunjukkantingkatperkembangan peserta didik dalam belajar yang dapat diamati dari kemajuan-kemajuan yang mereka capai, kekurangan-kekurangan yang ada dan lain-lain. Analisis yang dapat diberikan terhadap hasil pengamatan yang telah dilakukan terhadap prestasi yang dapat dicapai secara kualitatif adalah: ada 9 orang siswa $(29,03 \%)$ yang mencapai nilai diatas KKM, 13 orang siswa (41,94\%) mencapai nilai KKM namun ada 9 orang siswa $(29,03 \%)$ yang nilainya masih dibawah KKM. Jadi sebanyak 70,97\% siswa termasuk aktif belajar, giat belajar untuk mencapai prestasi sesuai harapan. Selanjutnya diberikan analisis kuantitatifnya mengingat data yang diperoleh adalah dalam bentuk angka sebagai berikut: Rata-rata $($ mean $)=76,45$.
Median (titik tengahnya) $=78,00$. Modus (angka yang paling banyak/paling sering muncul) setelah diasccending/diurut adalah 78,00. Banyak kelas $(\mathrm{K})=6$. Rentang kelas $(\mathrm{r})=17$. Panjang kelas interval (i) $=3$

Tabel 1. Data Interval Kelas Siklus I

\begin{tabular}{|c|c|c|c|c|}
\hline $\begin{array}{l}\text { No } \\
\text { Urut }\end{array}$ & Interval & $\begin{array}{c}\text { Nilai } \\
\text { Tengah }\end{array}$ & $\begin{array}{c}\text { Frekuensi } \\
\text { Absolut }\end{array}$ & $\begin{array}{c}\text { Frekuensi } \\
\text { Relatif }\end{array}$ \\
\hline 1 & $65-67$ & 66 & 2 & 6.45 \\
\hline 2 & $68-70$ & 69 & 5 & 16.13 \\
\hline 3 & $71-73$ & 72 & 0 & 0.00 \\
\hline 4 & $74-76$ & 75 & 2 & 6.45 \\
\hline 5 & $77-79$ & 78 & 13 & 41.94 \\
\hline 6 & $80-82$ & 81 & 9 & 29.03 \\
\hline \multicolumn{3}{|c|}{ Total } & 31 & 100 \\
\hline
\end{tabular}

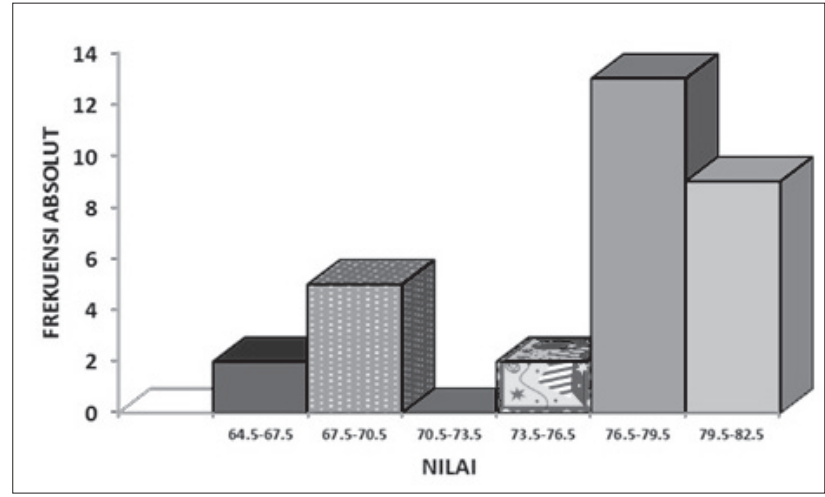

Gambar 2.

Histogram Meningkatkan Prestasi Belajar Agama Hindu Siswa Kelas VIII ${ }^{6}$ Semester II SMP Negeri 6 Denpasar

Tahun Pelajaran 2016/2017 pada Siklus I

Sintesis yang dapat disampaikan adalah ada 9 orang $(29,03 \%)$ dari 31 siswa memperoleh nilai diatas KKM, 13 orang $(41,94 \%)$ memperoleh nilai KKM namun masih ada 9 orang $(29,03 \%)$ siswa yang tergolong belum mampu memenuhi pencapaian keberhasilan pada siklus ini. Dari data yang diperoleh dapat diberikan sintesis bahwa usulan keberhasilan pada siklus I belum terpenuhi.

Sesuai fakta yang berhasil ditemui di lapangan, pada siklus I ini ditemukan beberapa kekurangan-kekurangan dan kelebihankelebihan yang mesti dijabarkan. Kekurangankekurangan yang ada: 1) Pelaksanaan pembelajaran belum maksimal akibat kemampuan siswa menerima dan meresapkan materi yang diajar belum mampu dioptimalkan. 2) Anak-anak agak sulit dimotivasi untuk giat 
belajar karena ada kecenderungan dari mereka lebih senang bermain-main. 3) Guru belum menemukan cara untuk menumbuhkan emosi agar anak giat dalam melakukan tugas-tugas yang disuruh. Kelebihan yang ada adalah: 1) Bahan pembelajaran telah diupayakan persiapannya dengan sebaik-baiknya untuk membantu siswa giat belajar. 2) Pengelolaan kelas sudah diupayakan dan bimbingan terhadap anak juga sudah dilakukan dengan maksimal. 3) Penulis sebagai guru di sekolah ini telah giat mengajar dan telaj mengeluarkan energi dan keringat yang cukup banyak.

\section{Deskripsi Siklus II}

Perencanaan II. Mengacu pada kelemahankelemahan yang masih ada pada siklus I, Rencana Pelaksanaan Pembelajaran (RPP) disusun ulang. Beberapa penekanan yang perlu dilakukan pada siklus II untuk mengatasi masalah yang dihadapi peserta didik yang masih tergolong kurang baik tingkat kemampuannya adalah: a) anak disuruh memilih teman dekatnya untuk mendiskusikan hal-hal yang sulit dipahami, b) dengan bantuan tersebut diharapkan dari kerja sama itu akan melahirkan ikatan emosi yang erat antar anak yang bias menumbuhkan tingkat keberanian dan kepercayaan dirinya. Dengan cara tersebut diharapkan kebiasaan anak yang tidak senang belakar akan dapat teratasi. Dengan demikian pembelajaran akan menjadi semakin menarik bagi anak yang tergolong lamban dalam berikir akan menjadi lebih bersemangat sehingga peningkatan yang diharapkan bisa terwujud.

Pelaksanaan II. Pelaksanaan siklus II difokuskan lebih banyak pada anak yang masih mengalami kesulitan dalam perkembangannya. Anak dibimbing dengan memberitahu hal-hal penting yang merupakan titik kunci penelaah masalah dan dengan sabar membantu mereka yang berkategoru kurang baik. Pembelajaran diupayakan tidak membosankan dan variasi permainan dijelaskan pada saat pembelajaran dilakukan agar pembelajaran tetap menarik. Bimbingan terus diupayakan dengan member contoh-contoh nyata, diharapkan dengan contoh-contoh tersebut peserta didik merasa termotivasi untuk belajar lebih giat.
Pengamatan/Observasi II. Pelaksanaan pengumpulan data dilakukan mengacu pada criteria penilalain yang telah ditetapkan. Upaya keras guru untuk melatih keberanian anak, meningkatkan kepercayaan diri, dan mengokohkan jalinan kemampuan mereka, memantau sikap mental mereka dan mencek perubahan yang terjadi.

Refleksi II. Hasil yang diperoleh dari penilaian prestasi belajar menggunakan tes dapat dijelaskan : dari 31 orang siswa ada 20 orang siswa $(64,52 \%)$ yang mendapat nilai diatas KKM dan 11 orang siswa $(34,48 \%)$ memperoleh nilai sama dengan KKM. Artinya siswa-swa tersebut sangat antusias mengikuti proses pembelajaran dan mau mengajukan diri serta bertanya pada guru di sela-sela pembelajaran sedang berlangsung. Indikator keberhasilan penelitian yang telah ditetapkan menyebutkan bahwa penelitian akan dihentikan atau tidak dilanjutkan ke siklus berikutnya apabila 85\% siswa berhasil mencapai nilai ratarata KKM atau melebihi KKM. Pada penilaian ini ternyata sudah $100 \%$ siswa yang berhasil mencapai kriteria tersebut artinya bahwa indikator keberhasilan penelitian yang diharapkan sudah dapat dicapai. Selanjutnya karena data yang diperoleh adalah data dalam bentuk angka, maka dilanjutkan dengan analisis kuantitatif sebagai berikut: Rata-rata (mean) = 81,71. Median (titik tengahnya) $=80$. Modus (angka yang paling banyak/paling sering muncul) setelah diasccending/diurut $=78$. Banyak kelas $(\mathrm{K})=6$. Rentang kelas $(\mathrm{r})=92-78$ $=14$. Panjang kelas interval $(\mathrm{i})=3$

Tabel 2. Data Interval Kelas Siklus II

\begin{tabular}{|c|c|c|c|c|}
\hline $\begin{array}{l}\text { No } \\
\text { Urut }\end{array}$ & Interval & $\begin{array}{l}\text { Nilai } \\
\text { Tengah }\end{array}$ & $\begin{array}{c}\text { Frekuensi } \\
\text { Absolut }\end{array}$ & $\begin{array}{c}\text { Frekuensi } \\
\text { Relatif }\end{array}$ \\
\hline 1 & $78-80$ & 79 & 16 & 51.61 \\
\hline 2 & $81-83$ & 82 & 3 & 9.68 \\
\hline 3 & $84-86$ & 85 & 10 & 32.26 \\
\hline 4 & $87-89$ & 88 & 0 & 0.00 \\
\hline 5 & $90-92$ & 91 & 2 & 6.45 \\
\hline 6 & $93-95$ & 94 & 0 & 0.00 \\
\hline \multicolumn{3}{|c|}{ Total } & 31 & 100,00 \\
\hline
\end{tabular}




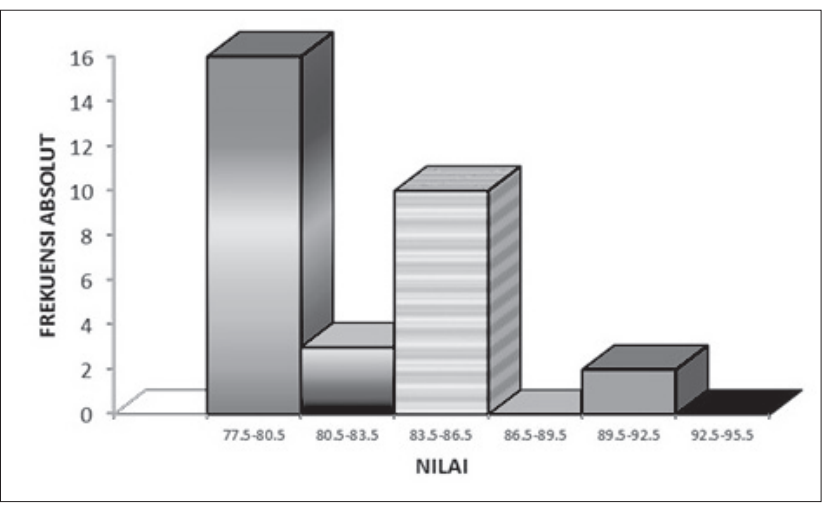

Gambar 3.

Histogram Meningkatkan Prestasi Belajar Agama Hindu Siswa Kelas VIII ${ }^{6}$ Semester II SMP Negeri 6 Denpasar Tahun Pelajaran 2016/2017 pada Siklus II

Sintesis yang dapat diberikan adalah dari 31 siswa yang diteliti ternyata hasilnya sudah sesuai dengan harapan. Upaya perbaikan telah dapat dilaksanakan dengan maksimal, keefektifan waktu belajar sudah mampu diupayakan dan terlihat anak sudah sangat senang dalam belajar.

Penilaian yang dapat diberikan terhadap pelaksanaan siklus II ini yaitu pembelajaran dengan penerapan metode contoh kasus dan diskusi interaktif dalam pembelajaran ekspository telah mampu dilaksanakan dengan sebaik-baiknya. Semua kekurangan-kekurangan yang ada sudah diperbaiki pada siklus ini, sehingga tidak ada yang masih perlu diragukan bahwa indicator yang dituntut untuk diselesaikan tidak ada lagi yang tertinggal. Semua hasil yang diperoleh pada siklus II ini menunjukkan bahwa penelitian ini sudah berhasil.

Data awal menunjukkan rendahnya prestasi belajar siswa yang baru mencapai ketuntasan $32,26 \%$. Dari data tersebut banyak terjadi kelemahan-kelemahan atau kekurangankekurangan dalam pelaksanaan proses pembelajaran akibat cara pembelajaran yang dilakukan masih yang sehari-hari dilakukan tanpa mau melihat teori-teori baru. Pada Siklus I diperoleh data dari pelaksanaan penelitian sudah ada 70,97\% siswa mencapai nilai sama dengan KKM dan di atas KKM serta 29,03\% siswa yang masih tertinggal. Untuk data ini belum sesuai dengan harapan indikator keberhasilan penelitian yang dicanangkan yaitu lebih dari 85\% siswa mampu mencapai keberhasilan sesuai KKM. Data yang diperoleh pada Siklus I ini menunjukkan persentase pencapaian peningkatan prestasi belajar anak belum memenuhi harapan sesuai ketercapaian indikator keberhasilan penelitian sehingga penelitian ini masih perlu untuk dilanjutkan ke siklus berikutnya. Selanjutnya, pada siklus ke II ini diperoleh data dari hasil penelitian yaitu $100 \%$ siswa mampu mencapai tingkat perkembangan melebihi tuntutan indikator. Dari semua data yang diperoleh, ternyata indikator keberhasilan penelitian yang menuntut $85 \%$ lebih siswa sudah pada tingkat mampu sudah tercapai. Oleh karenanya penelitian ini tidak dilanjutkan ke siklus berikutnya.

\section{PENUTUP}

Analisis yang telah dilakukan dan pembahasan yang telah disampaikan menggambarkan dengan jelas bahwa penerapan metode contoh kasus dan diskusi interaktif dalam pembelajaran ekspository yang telah diupayakan sesuai teori-teori yang ada, dalam pelaksanaan proses pembelajaran pada siswa kelas VIII ${ }^{6}$ telah berjalan dengan baik dan lancar. Hal yang dilakukan untuk mendukung keberhasilan tersebut yaitu perencanaan yang baik dan lancar. Hal yang dilakukan untuk mendukung keberhasilan tersebut yaitu perencanaan yang baik, pelaksanaan yang maskimal, obeservasi/pengamatan/ pengumpulan data menggunakan tes sesuai harapan indikator dan dilakukan dengan penjagaan yang ketat untuk memperoleh hasil sesuai tuntutan yang diharapkan. Setelah dilakukan refleksi ternyata hasil yang diperoleh sudah meningkat dari rata-rata awal 69,87 meningkat menjadi 76,45 pada siklus I dan meningkat menjadi 81,71 pada siklus II. Dari data yang disampaikan sudah terjadi peningkatan pada dua pihak yaitu di pihak guru mampu melaksanakan pembelajaran dengan lebih baik dan di pihak siswa sudah terjadi peningkatan keuletan, keaktifan, semangat, keinginan hingga hasil yang diperoleh dapat meningkat sesuai harapan. 
Meningkatkan prestasi belajar siswa setelah penerapan metode contoh kasus dan diskusi interaktif dalam pembelajaran ekspository maka dapat disampaikan saran-saran sebagai berikut: 1) Utamanya kepada teman guru, hendaknya dalam melaksanakan proses pembelajaran jika bermasalah terhadap prestasi belajar siswa, penggunaan metode contoh kasus dan diskusi interaktif dalam pembelajaran ekspository semestinya menjadi pilihan dari beberapa metode yang ada mengingat metode ini telah terbukti dapat meningkatkan penguasaan materi secara tuntas, yang berimplikasi kepada prestasi belajar. 2) Bagi peneliti lain, bahwa walaupun penelitian ini sudah dapat membuktikan efek utama dari metode contoh kasus dan diskusi interaktif dalam pembelajaran ekspository dalam meningkatkan prestasi belajar, sudah pasti dalam penelitian ini masih ada hal-hal yang belum sempurna dilakukan, oleh karenanya bagi yang berminat meneliti topik yang sama untuk meneliti maka disarankan meneliti topik yang sama tetapi lebih difokuskan kepada halhal yang belum terjangkau pada penelitian ini. 3) Kepada pembaca selanjutnya diharapkan untuk mengadakan penguatan, atau pengembangan melalui verifikasi data dan faksa hasil penelitian.

\section{DAFTAR PUSTAKA}

Arikunto, Suharsimi; Suhardjono; Supardi. 2006. Penelitian Tindakan Kelas. Jakarta: PT Bumi Aksara. Djamarah, Syaful Bahri. 1994. Prestasi Belajar dan Kompetensi Guru. Surabaya: Usaha Nasional.

Sardiman. 1988. Interaksi dan Motivasi Belajar-Mengajar Pedoman bagi Guru dan Calon Guru. Jakarta: Rajawali Pers.

Sanjaya, Wina. 2009. Strategi Pembelajaran Berorientasi Standar Proses Pendidikan. Kencana Prenada Media: Jakarta.

Somantri. 2001. Menggagas Pembaharuan Pendidikan IPS. Bandung: PT. Remaja Rosdakarya.

Sudjana, Nana. 2005. Dasar-Dasar Belajar Mengajar. Bandung: Sinar Baru Algesindo.

Suratmi, Mamik. 1994. Beberapa Faktor Penyebab Kesulitan Belajar Matematika Siswa SMAN Wilayah Kota Singaraja. Tesis. Program Pasca Sarjana Institut Keguruan dan Ilmu Pendidikan, Malang.

Suryabrata, Sumadi. 2000. Pengembangan Alat Ukur Psikologis. Yogyakarta: Penerbit Andi.

Tim Prima Pena. Kamus Besar Bahasa Indonesia. Gramedia Press.

Wojowasito. 1982. Kamus Umum Lengkap Inggris Indonesia - Indonesia Inggris. Malang: Delta Citra Grafindo.

Yamin, H. Martinis dan Maisah. 2009. Manajemen Pembelajaran Kelas. Strategi Meningkatkan Mutu Pembelaaran. Penerbit: Gaung Persada (GP) Press Jakarta. 